\title{
The Relationship between EFL Learners' Self-Regulation and Their Listening Comprehension
}

\author{
Mohammad Ali Fatemi \\ Islamic Azad University, Torbat-e- Heydarieh Branch, Iran \\ E-mail: matorbat@gmail.com \\ Maral Alishahi (Corresponding author) \\ Islamic Azad University, Torbat-e- Heydarieh Branch, Iran \\ E-mail: maral.alishahi@gmail.com \\ Maryam Noori Khorasani \\ Islamic Azad University, Torbat-e- Heydarieh Branch, Iran \\ E-mail: maryamnoorikhorasani@yahoo.com \\ Monir Seifi \\ Islamic Azad University, Torbat-e- Heydarieh Branch, Iran \\ E-mail: seifi.monir@gmail.com
}

Doi:10.7575/aiac.alls.v.5n.4p.198

Received: 17/06/2014

URL: http://dx.doi.org/10.7575/aiac.alls.v.5n.4p.198

Accepted: 04/08/2014

\begin{abstract}
Self-regulated EFL students can comprehend better what they listen. The present study sought to investigate the relationship between EFL learners' listening comprehension and their self-regulation. To achieve the goals of this study, 103 intermediate EFL learners were selected in Torbat-e- Heydarieh, Iran. Two instruments were employed and the participants were to complete; first, Motivated Strategies for Learning Questionnaire (MSLQ) to assess their SelfRegulation; and second, Standard Listening Test (SLT) to measure their listening comprehension. Results of Pearson Correlation Coefficient indicated a statistically significant correlation. This finding provides pedagogical implications for EFL teachers to use self-regulatory approach when teaching listening comprehension.
\end{abstract}

Keywords: Self-regulation, listening comprehension, EFL

\section{Introduction}

Zimmerman (2002) defines self-regulation as ones' ability to devise thoughts, feelings and actions which result in obtaining his/her goals. Highly regulated people can be compatible to various situations and come up with a solution while approaching a task in a confident tenacious purposeful mode (Zimmerman, 2002). According to Bandura (1986), learners need to pass through three processes to be self-regulated: self observation, self judgment and self-reaction. According to Pintrich's model (2000) there are four regularly cognitive recurring cycles. The first cycle deals with planning, goal targeting and also assessing the presupposition related to approaching a task. The second cycle involves a different self-monitoring process indicating cognitive self-awareness and personal learning strategies. The third one is related to different dimensions of self-control/regulation and the task in situations. In cycle four, one's reactions or reflections of the process are revealed. Zimmerman (2000) proposed three recurring stages for self-regulation process including forethought (premeditation), performance (implementation) or volitional control (decision making control). The first stage is associated with those activities done earlier than learning; e.g., students' motivation, self-efficacy, goal setting and planning. In the second stage, the learner concentrates upon the task to increase this/her performance; e.g., careful attention, taking notes and monitoring. In this stage, students compare their performance with the standard or goal and try to find the reason of the differences if any.

Regarding the relationship between self-regulation and listening comprehension in the contexts of English as foreign language (EFL), the stages discussed above should be taken into the EFL learners' account. Recently listening comprehension has been considered as an active process in which EFL learners are considered as active agents. Until recently, the nature of listening in a second language was disregarded by applied linguists, and it was often proposed that listening skills could be acquired via exposure but not really taught. This position has been replaced by an active interest in the role of powerful theories of the nature of language comprehension, and by including carefully developed listening courses in many ESL programs (Barani, 2011). The listening skill is theoretically considered as "an active process in which individuals focus on selected aspects of aural input, construct meaning from passages, and relate what 
they hear to existing knowledge" (O'Malley, Chamot, and Kupper, 1989, p. 418). Definitions proposed for selfregulation can provide support for relating this psychological trait to listening comprehension among EFL students.

According to Zare-ee (2007), listeners should do different tasks in order to understand speech in a foreign language. They need to rely on different types of knowledge including lexical knowledge, grammatical knowledge, and sociocultural knowledge (Bacon, 1989, Shrum \& Glisan, 1999, as cited in Zare-ee, 2007). They must be able to organize and remember what is presented by giving 'conscious attention to the sounds for the purpose of gaining meaning' (Thanjaro, 2000, p.16, as cited in Zare-ee, 2007) and by spending enough time to become sure of occurrence of the comprehension and the intake of the second-language information (Zare-ee, 2007). Therefore, the present correlation study seeks to examine the relationship between Iranian intermediate EFL learners' self-regulation and their listening comprehension.

\section{Research question}

The following research question was posed by the researchers to achieve the goals of the present study:

Q: Is there any significant relationship between EFL learners' self-regulation and their listening comprehension?

\subsection{Research null-hypothesis}

Accordingly the following research null-hypothesis was formulated:

H0: There is not any significant relationship between EFL learners' self-regulation and their listening comprehension.

\section{Review of literature}

Zimmerman (2002) states that those who are highly regulated can be compatible to various situations and are able to find an appropriate solution while approaching a task in a purposeful manner. Previous relevant literature has devoted much attention to self regulation as one of the important EFL learners' psychological traits.

Talebinezha and Negari (2009) investigated the effect of concept mapping as a learning strategy on EFL students' selfregulation (metacognitive self-regulation, time and study environment, effort regulation, peer learning, and help seeking). It was found that students gained higher self-regulation in writing tasks as the result of the explicit instruction of the concept mapping strategy (Talebinezha \& Negari, 2009). It seems that, Talebinezha and Negari explained, the employment of concept mapping strategy in the courses of writing in the university has been rewarding as a means of constructing knowledge and improving self-regulation.

Khajavi and Abbasian (2013), for example, investigated if concept mapping as a cognitive tool could enhance EFL students' self-regulation in a reading course. It was found that there was a significant difference between the two groups with students in the experimental group (receiving concept mapping) performing better than those in the control group on self-regulation in reading (Khajavi \&Abbasian, 2013).

Haji Hassan Hamedani (2013) investigated the relationship between self-efficacy and self-regulation in vocabulary acquisition with Iranian EFL learners. Statistical analyses indicated that there is a significant relationship between selfefficacy and self-regulation in vocabulary acquisition among the participants (Haji Hassan Hamedani, 2013).

Latifi, Tavakoli, and Dabaghi (2014) investigated the effectiveness of a self-regulatory approach on the improvement of listening comprehension ability of EFL learners. The results revealed that both High and Low Skilled participants of experimental groups achieved a significant improvement at the end of the study. Both High and Low Skilled groups had a considerable achievement after the treatment. Besides, the researcher found a better improvement rate for the Low Skilled experimental groups. In the pre-test data analysis, the High Skilled groups performed better than the Low Skilled ones, while on the post test, the Low skilled groups had a slightly better mean score (although not significantly). The results indicate that teaching listening comprehension via a self-regulatory approach can result in better language learners who will learn to orchestrate their listening comprehension process better (Goh, 2000, as cited in Latifi et al., 2014).

\section{Methodology}

A sample population including 103 Iranian intermediate EFL learners studying in Torbat-e-Heydarieh, Iran was selected based on Krejcie-Morgan table (1970) out of 140 students. Their age ranged from 22 to 30. Both males and females took part in this study. Table 1 presents the results of one set of these calculations. It may be employed by researchers to select the appropriate sample size for almost any study. 
Table 1. Table for determining sample size for a given population

\begin{tabular}{|cc|cc|cc|cc|cc|}
$\mathrm{N}$ & $\mathrm{S}$ & $\mathrm{N}$ & $\mathrm{S}$ & $\mathrm{N}$ & $\mathrm{S}$ & $\mathrm{N}$ & $\mathrm{S}$ & $\mathrm{N}$ & $\mathrm{S}$ \\
\hline 10 & 10 & 100 & 80 & 280 & 162 & 800 & 260 & 2800 & 338 \\
15 & 14 & 110 & 86 & 290 & 165 & 850 & 265 & 3000 & 341 \\
20 & 19 & 120 & 92 & 300 & 169 & 900 & 269 & 3500 & 246 \\
25 & 24 & 130 & 97 & 320 & 175 & 950 & 274 & 4000 & 351 \\
30 & 28 & 140 & 103 & 340 & 181 & 1000 & 278 & 4500 & 351 \\
35 & 32 & 150 & 108 & 360 & 186 & 1100 & 285 & 5000 & 357 \\
40 & 36 & 160 & 113 & 380 & 181 & 1200 & 291 & 6000 & 361 \\
45 & 40 & 180 & 118 & 400 & 196 & 1300 & 297 & 7000 & 364 \\
50 & 44 & 190 & 123 & 420 & 201 & 1400 & 302 & 8000 & 367 \\
55 & 48 & 200 & 127 & 440 & 205 & 1500 & 306 & 9000 & 368 \\
60 & 52 & 210 & 132 & 460 & 210 & 1600 & 310 & 10000 & 373 \\
65 & 56 & 220 & 136 & 480 & 214 & 1700 & 313 & 15000 & 375 \\
70 & 59 & 230 & 140 & 500 & 217 & 1800 & 317 & 20000 & 377 \\
75 & 63 & 240 & 144 & 550 & 225 & 1900 & 320 & 30000 & 379 \\
80 & 66 & 250 & 148 & 600 & 234 & 2000 & 322 & 40000 & 380 \\
85 & 70 & 260 & 152 & 650 & 242 & 2200 & 327 & 50000 & 381 \\
90 & 73 & 270 & 155 & 700 & 248 & 2400 & 331 & 75000 & 382 \\
95 & 76 & 270 & 159 & 750 & 256 & 2600 & 335 & 100000 \\
\\
Note:
\end{tabular}

\subsection{Instrumentations}

In order to collect required data to check the null-hypotheses proposed by the researcher the following instruments were employed:

\section{- Motivated Strategies for Learning Questionnaire (MSLQ)}

In order to collect data on the students' self-regulation, MSLQ developed by Printrich, Smith, Garcia, and McKeachie. (1991) was employed. The questionnaire consisted of 31 multiple-choice items. Responses were scored using a 5 point Likert scale ranging from 'Not at all true of myself' to 'True of myself'. The difficult items of the questionnaire were explained by the researcher. Participants had to complete the questionnaire in 25 minutes.

\section{- $\quad$ Standard Listening Test (SLT)}

To assess the participants' listening comprehension, a test adopted from Basic Tactics for Listening ( $3^{\text {rd }}$ edition) developed by Richards (2010) was employed and the participants' performances were recorded. Unit 20 of the book was selected and every individual participant was allowed to answer to the items in 5 minutes. The test was administered by the three researchers.

\subsection{Procedure}

Firstly a sample ( $\mathrm{N}=103$, both males\& females) of intermediate EFL students in Torbat-e-Heydarieh were selected based on Krejcie-Morgan Table (1970). Participants were provided with two interments including Motivated Strategies for Learning Questionnaire (MSLQ) in order to assess the participants' self-regulation, and a Standard Listening Test (SLT) in order to assess the participants' performances in listening comprehension. MSLQ was developed by Printrich, Smith, Garcia, and McKeachie. (1991). Listening test was adopted from Richards' (2010) Basic Tactics for Listening ( $3^{\text {rd }}$ edition). Time allocated for completing MSLQ was 25 minutes; also every participant had to respond to listening comprehension items in 5 minutes. Having employed SPSS, Pearson Correlation Coefficient Analysis was conducted to check if there is a statistically significant relationship between these participants' selfregulation and their listening comprehension.

\section{Data Analysis}

To check the null-hypothesis stating that" There is not any significant relationship between EFL learners' self-regulation and their listening comprehension" the Pearson Product-Moment Correlation Formula was employed. Table 2 shows the results.

Table 2. Results of person Pearson Correlation Coefficient for the variables

\begin{tabular}{llrr}
\hline \multicolumn{4}{c}{ Correlations } \\
\hline Listenin & Pearson Correlation & 1 & $\begin{array}{c}\text { Self- } \\
\text { regulation }\end{array}$ \\
$\mathrm{g}$ & Sig. (2-tailed) & & $.482^{* *}$ \\
& $\mathrm{~N}$ & 103 & .000 \\
Self- & Pearson Correlation & $.482^{* *}$ & 103 \\
regulati & Sig. (2-tailed) & .000 & 1 \\
on & $\mathrm{N}$ & 103 & 103 \\
$* *$. Correlation is significant at the 0.01 level (2-tailed). \\
\hline
\end{tabular}


As Table 2 shows, there is a significant relationship between these participants' listening comprehension and their selfregulation (corr $=.482, \mathrm{p}=.000$ ). It can be concluded that self-regulated EFL students can achieve higher scores in listening comprehension test.

\section{Discussion and conclusion}

The purpose of the present study was to investigate the relationship between Iranian intermediate EFL learners' listening comprehension and their self-regulation. Accordingly the following null-hypothesis was proposed by the researcher:

H0: There is not any significant relationship between EFL learners' self-regulation and their listening comprehension.

To test the null-hypothesis Pearson Product-Moment Correlation Formula was employed. Having analyzed the data collected from the instruments, it was found that there was a statistically significant relationship between the above mentioned variables $(\mathrm{p}=.000)$. According to this finding, it can be concluded that the participants with high level of selfregulation have achieved high listening scores. Similarly, Goh (2000) concludes that teaching listening comprehension via a self-regulatory approach can enhance language achievements of those learners who will learn to orchestrate their listening comprehension process better. Moreover, Zimmerman (2002) states that people with a high level of regulation can be compatible to different situations being able to find an appropriate solution while approaching a task in a purposeful manner. Accordingly, EFL teachers should implement self-regulatory approaches to improve their students' listening comprehension ability.

It is hoped that further studies will be done to investigate the effects of implementing modern digital learning tools on EFL learners' self-regulation in listening, writing, speaking and reading.

\section{References}

Bandura, A. (1986). Social foundations of thought and action: A social cognitive theory. Englewood Cliffs, NJ: Prentice Hall.

Barani, G. (2011). The Relationship between Computer Assisted Language Learning (CALL) and Listening Skill of Iranian EFL Learners. Procedia Social and Behavioral Sciences 15, 4059-4063.

Goh, C. (2000). A cognitive perspective on language learners' listening comprehension problems. System, 28, 55-75.

Haji Hassan Hamedani, S. (2013). The Relationship between Self-Efficacy and Self- Regulation in Vocabulary Acquisition of Iranian EFL Learners. Journal of Academic and Applied Studies,3(1),20-31.

Khajavi Y., \&Abbasian, R.(2013). Improving EFL Students' Self-regulation in Reading English Using a Cognitive Tool. The Journal of Language and Linguistic Studies, 9(1),206-222.

Latifi, M., Tavakoli, M., \& Dabaghi,A. (2014). The effects of a self-regulatory approach on the listening comprehension achievement of EFL learners. International Journal of Research Studies in Education,3(3), 67-78.

O'Malley, M.; A. U. Chamot; and L. Kupper (1989). Listening Comprehension Strategies in Second Language Acquisition. Applied Linguistics 10(4),418-437.

Pintrich, P. R. (2000). The role of goal orientation in self-regulated learning. In M. Boekaerts, P. R. Pintrich \& M. Zeidner (Eds.), Handbook of self-regulation (pp. 451-502). San Diego: Academic Press.

Printrich, P. R., D. A. Smith, T. Garcia, \& W. J. McKeachie. (1991). A manual for the use of the Motivated Strategies for Learning Questionnaire (MSLQ). National Center for Research to Improve Postsecondary Teaching and Learning. Ann Arbor: University of Michigan.

Richards. J.C. (2010). Tactics for Listening ( $3^{\text {rd }}$ edition). Oxford university press.

Talebinezha, M.R., \& Negari,G. (2009). The Effect of Explicit Teaching of Concept Mapping in Expository Writing on EFL Students' Self-regulation. Pazhuhesh-e Zabanha-ye Khareji, (49), 85-108.

Zare-ee, A. (2007). The Significance of Pauses in EFL Listening Comprehension Tests. Online available at : repo.uum.edu.my/3215/1/Ab2.pdf.

Zimmerman, B. J. (2002). Becoming a self-regulated learner: An overview. Theory into Practice, 41(2), 64-70. 